\title{
Quentin Skinner's Revised Historical Contextualism: A Critique
}

\section{Keywords}

history of ideas; linguistic contextualism; methodology; Skinner; perennial; ideology.

\begin{abstract}
Since the late 1960s Quentin Skinner has defended a highly influential form of linguistic contextualism for the history of ideas, originally devised in opposition to established methodological orthodoxies like the 'great text' tradition and a mainly Marxist epiphenomenalism. In 2002, he published Regarding Method, a collection of his revised methodological essays that provides a uniquely systematic expression of his contextualist philosophy of history. Skinner's most arresting theoretical contention in that work remains his well-known claim that past works of political theory cannot be read as contributions to 'perennial' debates but must instead be understood as particularistic, ideological speech-acts. In this article I argue that he fails to justify these claims and that there is actually nothing wrong at all with (where appropriate) treating past works of political theory as engaged in perennial philosophical debates. Not only do Skinner's arguments not support the form of contextualism he defends, their flaws are actually akin to those he identified in his critique of previous methodological orthodoxies.
\end{abstract}

\section{Biographical Note}

Robert Lamb is Lecturer in Political Philosophy at the University of Exeter. His main research interests are in the history of $18^{\text {th }}$ and $19^{\text {th }}$ century British thought, normative political theory and the methodology of the history of ideas. He has published articles in Journal of the History of Ideas, History of Political Thought, The Review of Politics, European Journal of Political Theory, Utilitas and Journal of the Philosophy of History and he is currently working on what he hopes will eventually be a monograph on the political thought of Thomas Paine. 


\section{Quentin Skinner's Revised Historical Contextualism: A Critique}

\section{Robert Lamb ${ }^{1}$}

\section{Introduction}

The 'historical contextualist' turn in the Anglophone study of the history of political thought since the late 1960s has been thoroughly documented (e.g. Tuck, 1993; Castiglione, 1993; Hampsher-Monk, 2001; Bevir, forthcoming). Contextualist approaches to the subject initially conceived of and deployed by a group of scholars often loosely grouped together as the 'Cambridge School' have gradually acquired something of an orthodox status in the last forty years. ${ }^{2}$ More than any other figure associated with the Cambridge School, Quentin Skinner has provided a sustained and eloquent philosophical justification of historical contextualism through a variety of influential articles, which have delineated a workable interpretive method, furnished it with a theoretical justification and also actually applied it to the work of individual political thinkers. In 2002, Skinner published Visions of Politics, a three-volume collection of his writing, the first of which contains his various articles on method, hitherto scattered in different journals and edited volumes. Comprehensively revised and arranged in logical (rather than chronological) order, the ten essays that comprise the volume provide a usefully systematic statement of the strand of contextualism that he has defended and that has proved so popular amongst historians of political thought.

His aim in substantially revising and representing his methodological essays for the twenty-first century is not merely to provide an historical document of the arguments he advanced in the 1960s and 1970s. It is rather, he claims, to offer an 'articulation and defence' of 'a properly historical' approach to understanding 
political thought (2002: vii). For many (e.g. Pocock, 2004), bringing the essays together simply further reveals the strengths of Skinner's initial contentions and why they have proved so successful in unseating previously popular interpretive orthodoxies. However, revisions to his methodology and its exposition in such a systematic way actually raise the possibility of more clearly revealing its flaws. Indeed, as one reviewer recently noted, in altering key components of his methodological arguments and presenting them in such a unified manner, Skinner has given critics 'new targets at which to aim and shoot' (Ball, 2007: 363). My aim in this article is to identify such targets and argue that Skinner's contextualism as outlined in Visions of Politics is indefensible. Rather than stressing the various developments in his thought ${ }^{3}$, I will consider his revised historical contextualism as the statement of a coherent philosophy of history and advance two related criticisms, which both concern certain inflexibilities that it seems to rely on: unjustifiably fixed assumptions about the nature of history, politics and philosophy. Though the tone of the article is inevitably quite critical, the ultimate objective is constructive: making the case against Skinner's overly narrow strand of contextualism not only leaves room for a broader historicism, it also carves open a space for rethinking the relationship between the study of political theory on the one hand and the study of its history on the other.

The structure of the article is as follows. I begin by briefly discussing the emergence of Cambridge School historical contextualism as a movement within the study of political thought and show how it can be viewed as a self-conscious critical response to two previously reigning methodological orthodoxies: the 'great text' tradition and epiphenomenalism. ${ }^{4}$ The discussion of these displaced orthodoxies is not intended to serve as historical exegesis, since part of my argument is that Skinner's revised methodology actually is undermined by problems akin to those he attributes to 
these other approaches. ${ }^{5}$ I then move on to the methodological justification that Skinner provides for his revised historical contextualism. He explicitly restates his well-known rejection of other interpretive approaches, focusing especially on those that work on the presumption that past texts can be treated as housing abstract philosophical arguments capable of addressing problems that lie beyond their immediate temporal horizons. Skinner denies that any such 'perennial' problems actually exist and from this denial claims that only his contextualist alternative can provide an adequate interpretation of a text. I identify a flaw in his argument, which is akin to that he identifies with the 'great text' tradition and is revealed through conceptual analysis of what it means for something to be 'perennial'. I then move on to consider an additional argument against the possibility of perennial problems, one that has become explicit only in Visions of Politics and concerns the nature of authorial intentionality and its relationship to political action. I argue that the understanding of authorial intentionality Skinner outlines is unjustifiably narrow and appears to stem from his increasing invocation of elements of Nietzschean political theory. My suggestion is that by positing such a narrow understanding, he elides the distinction between individual intentions and motives in the same fashion as the epiphenomenal understanding that his contextualism has successfully discredited and unseated.

Before proceeding, it is necessary to acknowledge the possibility that my analysis runs the risk of misreading and therefore misrepresenting the nature of Skinner's project. Because Skinner is a historian of philosophy as well as a philosopher of history, who writes as a 'practising historian reflecting on the task in hand' (2002: 1) it is necessary to be attentive to the level at which his claims about the nature of interpretation are pitched. A useful way of thinking about this is provided by 
Mark Bevir who, in The Logic of the History of Ideas, draws a sharp distinction between claims about 'method' on the one hand and 'heuristics' on the other (1999: 910). As Bevir notes, a method 'in a strong sense, is a special procedure that enables scholars to reach a correct conclusion about something' and 'in a weak sense, is a special procedure without which scholars can not reach a correct conclusion about something'. Methods are distinct from heuristics because the latter 'merely provide a potentially fruitful way of reaching a correct conclusion about something'. Thus, any defence of a method, even in its weak sense will, unlike a defence of a heuristic technique, exclude forms of interpretation that eschew that method because such an eschewal will necessarily prevent correct interpretation. So, for example, a feminist method for correct interpretation in the history of ideas would require that any analysis make central use of, say, the concept of patriarchy, whereas a heuristic version of such a claim would merely suggest that the concept of patriarchy might provide a possibility for plausible interpretation. In the former case, correct interpretation depends on the use of certain concepts whereas the latter requires no such dependence. A methodological claim is, then, one that necessarily involves such a claim to exclusivity: it says either 'do X and you will interpret correctly', or at the very least 'without doing X you have no chance of correct interpretation'. Either way, methodological claims are claims about the necessary and sufficient conditions of correct interpretation. Heuristic claim are, by contrast, simply reflections on the art of interpretation and involve no such arguments about necessary and sufficient conditions.

Highlighting this distinction is important for the following discussion. This is because my whole argument rests on the belief that Skinner's philosophy of history comprises a method rather than a mere heuristic. ${ }^{6}$ This reading seems faithful to 
Skinner's intentions and it is certainly how many of his admirers like Tully (1988) and critics like Bevir (1999) have understood and represented his work. But several scholars do resist this reading of Skinner's project. For example, Kari Palonen (2000; 2002), appears to view it along more heuristic lines: for him, Skinner's writings on historical interpretation comprise a 'style' of political theorizing, one that seems not to involve any claims about necessary or sufficient conditions for understanding. According to this view, the historical contextualism he defends is simply one among many legitimate, strategic ways of reading, one that 'insists on the heuristic value of contingency in understanding' and is indebted to an underpinning 'perspectivism' (Palonen, 2003: 4, 1-28). Understanding Skinner's project along these lines has gained plausibility in recent years, partly because of the nature of his work as a practising historian (Skinner 1983; 1984; 1998) and partly because he has increasingly invoked a plurality of conceptual vocabularies to describe his work (see Bevir, forthcoming).

Nevertheless, the evidence for a heuristic reading of Skinner's writing on historical understanding looks scant and ambiguous at best. Several of his claims about the nature of interpretation are clearly indicative of a method in the strong sense identified above. As will become clear, this is most apparent in his assertion that past political texts cannot be read as works of abstract philosophy capable of contributing to contemporary debates: he remains committed to the view that modern philosophers 'cannot learn from the perennial wisdom contained in the classic texts' and explicitly rejects attempts to do so as 'inherently misguided' (Skinner, 2002: 5, 79, emphases added). Were Skinner's defence of contextualism intended simply to make the case for one among many forms of historical understanding, it would obviously lack the ability to describe any other interpretive approach as 'inherently' incorrect. Perhaps 
more importantly, if he were to embrace a heuristic reading of his project, there would likely be a heavy price to pay in terms of the enduring relevance of his thought. This price would be the entailment that his writing on this subject would be rendered of only limited and necessarily contingent interest to historians of philosophy and largely irrelevant to philosophers of history.

\section{Displaced Orthodoxies and Skinner's Contextualism}

As noted, Cambridge School historical contextualism has come to enjoy a dominant position within the study of the history of political thought. The main figures associated with the movement—Quentin Skinner, J.G.A. Pocock, John Dunn, Richard Tuck, James Tully and others - tend to be identifiable more by their work in the field than through any detailed methodological statements and those figures that have actually sought to offer an abstract philosophical defence of their approach remain a very small minority. In fact, forty years after the first, aggressive and influential defences of historical contextualism, Skinner and Pocock remain the only two figures that have attempted to provide their historical practice with comprehensive statements of their (quite distinct) interpretive philosophies. ${ }^{7}$ What is usually thought to define the Cambridge School is a commitment to a form of linguistic contextualism: the belief that political texts can only be understood correctly by locating them within their intellectual context and, in turn, that this intellectual context can only be properly understood in terms of the language available to individual authors. The key to understanding a text thus lies in understanding the language within which an author makes a particular statement: language is here understood simultaneously as a structural constraint (one that limits the actions of a particular author) and a resource for agency (one that provides the author with various available opportunities for 
action). ${ }^{8}$ This location of language as the source of both structure and agency

contrasts sharply with the other methodological traditions that the Cambridge School

has successfully usurped.

In fact, the success enjoyed by the Cambridge School approach is partly explicable through attention to the unhistorical nature of two previously popular methodological traditions. The first of these traditions is the 'great text' tradition of interpretation, which used the writings of past thinkers in order to discuss political problems of enduring resonance. The person with the most iconic association to this tradition is undoubtedly Arthur Lovejoy whose focus on 'unit-ideas' explicitly aimed to uncover the contributions of past thinkers to trans-historical political problems (Lovejoy, 1936; Skinner, 2002: 83-84). As critics pointed out, such an approach was thoroughly unhistorical in that it advanced interpretations based on the assumption that past thinkers were, as Iain Hampsher-Monk puts it, 'alive and well, and working just down the corridor' (1998: 38). Skinner memorably exposed the problems that bedevil this approach in his influential article 'Meaning and Understanding in the History of Ideas', first published in 1969 and revised and reprinted in Visions of Politics. Herein, Skinner suggests that according to the 'great text' account, The task of the historian of ideas is to study and interpret a canon of classic texts. The value of writing this kind of history stems from the fact that the classic texts in moral, political, religious and other such modes of thought contain a 'dateless wisdom' in the form of 'universal ideas'. As a result, we can hope to learn and benefit directly from investigating these 'timeless elements', since they possess a perennial relevance. This in turn suggests that the best way to approach these texts must be to concentrate on what each of them says about each of the 'fundamental concepts' and 'abiding questions' of morality, politics, religion, social life. We must be ready, in other words, to read each of the classic text 'as though it were written by a contemporary' (2002: 57).

As Skinner points out, the 'great text' assumption that past texts should be read for the purpose of shedding light on 'fundamental concepts', gave rise to 'a series of 
confusions and exegetical absurdities'. For example, Locke could be criticised for failing to make use of concepts to fill holes in his arguments despite the fact that those concepts would likely have been unrecognisable to him and Rousseau could be chastised as an apologist for totalitarian government, the emergence of which he has 'special responsibility’ for (Skinner, 2002: 77, 73). For Skinner (and the Cambridge School in general), the problem with such interpretations is that they unapologetically avoid any reference to the intentions of the author in question; rather, they merely engage in philosophical criticism or moral judgment such that 'history becomes a pack of tricks we play on the dead' (Skinner, 2002: 65).

The second methodological tradition successfully undermined by the Cambridge School was a prevalent epiphenomenalism: those historical approaches that appeared to deny the position of individuals' mental activities as the source of their utterances and instead privileged determinate social, political or economic structures in their analysis of meaning. Marxist and Namierite historians - despite their significant differences — both shared the denial of any causal relation between the principles held by an individual agent and the actions of that agent (Skinner, 2002: 145-46). Thus, for example, the Marxist approach—epitomised by the influential work of C.B. Macpherson (1962) — viewed past political theories through the lens of class and ideology and essentially treated the history of modern political thought as a history of the moral justification of capitalism by a variety of bourgeois thinkers. The Cambridge School worry about this sort of epiphenomenal approach expressed by Skinner and others was its reliance on an impoverished analysis of the historical context that framed the writings of the texts in question. ${ }^{9}$ Authorial intentions were not completely ignored but were rather treated as mere reflexes of structurally embedded social (or in the Marxist case, economic) structures. Such 
epiphenomenalism elided the distinction between an author's intentions in political writing on the one hand and her motives on the other (Skinner, 2002: 97-98). Instead, the former tended to be collapsed into the latter, so that interpretive interest focused not on the meaning the utterance had for the author as an individual but instead to the ideological motivation underlying it. Historical meaning was thus reduced to the proattitudes the author held or the ends she wished to accomplish in writing rather than to intentionality understood in the broader sense of the range of beliefs and mental states attributable to an individual.

Skinner's influential alternative, historical contextualist understanding of meaning utilises J.L. Austin's concept of 'speech acts': the insight that linguistic utterances or locutions are necessarily performative; when individuals say things, they do things in the process, like warning, declaring, promising and so on. His claim is that the meaning of an utterance is bound up in its illocutionary force; it is necessary to understand not just what the individuals words themselves mean (in a semantic sense) but instead what an actor was doing in saying such words to a particular person on a particular occasion. Skinner applies Austin's insight to historical texts, which he treats as political speech-acts, the performative nature of which seems especially clear. Consider, he suggests, the claim made by Machiavelli, that 'mercenary armies always undermine liberty' (2002: 116). As Skinner notes, whilst 'there is little difficulty about understanding the meaning of the utterance itself', this tells us nothing about what Machiavelli was doing in uttering it (2002: 116). In order to determine this, it is necessary to establish, for example, whether or not the opinion that Machiavelli is voicing a popularly accepted truism or expressing something novel, whether he was attempting to legitimate a given social norm or to advance an innovative argumentative statement. According to Skinner, the only way to settle the 
matter is to explore the dominant intellectual context of the time: 'by paying as close attention as possible to the context of [a particular] utterance, we can hope gradually to refine our sense of the precise nature of this intervention constituted by the utterance itself' (2002: 117).

The methodological entailments of Skinner's contention that analysis of an utterance requires attention to its illocutionary force are not themselves necessarily far-reaching. His claim is not sufficient to entail the historical particularity of an utterance and therefore not sufficient to defend the necessity of any historical contextualist approach to understanding it. The importance of determining the illocutionary force of an utterance can be admitted without this implying that it would be impossible or unwise to approach past political writings as comprising coherent philosophical statements that could be expressible and assessable in contemporary philosophical terms. This is because it could be established that the author of a particular text intended their arguments to be abstract enough to reach beyond immediate contextual horizons. If this intention were clear then it would seem to suggest that the illocutionary force of a particular utterance could (indeed, perhaps should) be appreciated as something of continuing comprehensibility, something that would seem to undermine the need for a narrow contextualist approach.

Thus, if a thinker seems to have been explicitly pitching his or her arguments at an abstract, philosophical level, there would be no reason to privilege a contextualist understanding of that argument. Historians of political thought can thus say things like 'Hume held view $\mathrm{X}$ about the problem of induction' or 'Hobbes held view Y about the question of human freedom'. In fact, despite the considerable influence of the Cambridge School on historical practice, abstract philosophical readings of historical texts continue to flourish both at scholarly and pedagogical levels and the 
parties involved fail to express any embarrassment at this. Thus, the influential analytic, philosophical interpretations of Hobbes by Gregory S. Kavka (1986) and of Marx by G.A. Cohen (1978) seem to have been undertaken without any contextualist worries. Even more recently, Jeremy Waldron's work on Locke's political thought proceeds from the explicitly anti-contextualist contention that it contains 'as wellworked-out a theory of basic equality as we have in the canon of political philosophy', one capable of informing and illuminating contemporary philosophical discussions (2002: 8). Also recently, in a similar vein, Michael Otsuka's Libertarianism without Inequality aims to use Locke's thought to contribute to 'topics of contemporary concern among analytic political philosophers' (2003: 1). Clearly, all these interpretations of past texts that focus on abstract arguments rely on the belief that it is possible for the utterances of past thinkers to contribute to philosophical problems of trans-historical interest.

Notably, Skinner's revised historical contextualism remains committed to a rejection of not merely the efficacy or value of such philosophical approaches to past political writings, but even their very legitimacy. Thus, when considering the suggested benefits of the common practice of "concentrating on what each writer says about' an abstract political or philosophical problem 'by treating them as selfsufficient objects of enquiry', he makes the following declaration:

One might retort, however, that with sufficient care and scholarship such dangers can surely be avoided. But if they can be avoided, what becomes of my initial claim that there is something inherently misguided about this approach? By way of answer, I wish to advance a thesis complementary to, but stronger than, the one I have so far defended. The approach I have been discussing...cannot in principle enable us to arrive at an adequate understanding of the texts we study in the history of thought (2002: 79, emphases added).

In this passage, Skinner is quite unequivocal: there is something 'inherently misguided' about attempting to interpret the abstract philosophical statements made 
within past political texts even where 'sufficient care and scholarship' is in evidence; such approaches 'cannot in principle' lead to successful interpretation. The interpretive efforts noted above that concentrated precisely on what the work of Locke or Marx 'says' about an abstract problem are therefore, according to Skinner, necessarily destined to fail. And it is through this rejection of such an abstract philosophical analysis of texts that he is able to defend his historical contextualist speech-act analysis, which stresses the necessarily particular nature of political utterances.

\section{The Perennial}

Central to the justification that Skinner provides for his methodology is the claim that any argument is inevitably local or particular and because of this is unable to reach the level of abstraction necessary for it to be of trans-historical import. As he puts it,

any statement is inescapably the embodiment of a particular intention on a particular occasion, addressed to the solution of a particular problem, and is thus specific to its context in a way that it can only be naïve to try to transcend. The implication is not merely that the classic texts are concerned with their own questions and not with ours; it is also that - to revive R.G. Collingwood's way of putting the point - there are no perennial questions in philosophy. There are only individual answers to individual questions, and potentially as many different questions as there are questioners (2002: 88, emphases added).

For Skinner, as for Collingwood, there is no stable distinction to be made between history and philosophy: all philosophical questions are actually historical questions. Abstraction beyond contextual limits is impossible and belief that a philosophical statement can do so is 'naïve'. As historical actors inevitably address questions that are fundamentally different to our own, there are no 'perennial questions in philosophy'. 
There is nevertheless a very important distinction to be made between the statuses of the claims advanced by Collingwood and Skinner about historical particularity and how these relate to the possibility of 'perennial' questions or problems. Collingwood's claim — put forward in his Autobiography—is that there are no 'eternal' issues in philosophy, 'except so far as any historical fact could be called eternal because it had happened once for all, and accordingly because it had arisen once for all and once for all been solved' (Collingwood, 1970: 67-68). The way Skinner puts the point is slightly, but crucially, different: his claim is that there are "no perennial problems in philosophy' (2002: 88, emphasis added). This might appear the most minor of semantic alterations, but the concepts 'eternal' and 'perennial' actually have quite different significations and this difference has important implications for the relationship between philosophy and history. The term 'eternal' is usually thought to refer to something that has 'infinite duration', something 'without beginning or end'. Though often colloquially conflated with 'eternal', the term 'perennial' by contrast usually denotes something that lasts for a very long time — indeed, in botanical science it traditionally refers to a plant that continues its growth for at least three years.

Importantly, it is clear that this is not what Collingwood means by 'eternal', something he is keen to emphasise. He cautions against the misuse of the word 'eternal', by which he means the reduction of it to the meaning I have ascribed to the concept of 'perennial'. Thus, he claims that when the term 'eternal' is used simply 'as equivalent to "lasting for a considerable time", the term is employed in "its vulgar and inaccurate sense' (Collingwood, 1970: 68, n.1). There is thus a clear difference between the two terms and the concepts they denote. If this conceptual distinction is granted, then there are two different potential arguments to consider, each with 
different implications for the particularity of historical contexts. The first claim, about eternality, would suggest that no philosophical problem has infinite duration. The second, about the perennial, would suggest that no philosophical problem could last a long time. Because the theoretical statuses of these two claims are actually quite distinct, they have very different methodological implications. The contention that there are no eternal problems in philosophy appears to be an a priori claim. It is a rejection of a (presumably) quasi-realist or foundationalist belief that there are eternal issues that simply exist universally or transcendentally, perhaps as functions of eternal human needs and desires. It is therefore clearly an ontological statement that comprises a scepticism towards the existence of, as Bevir puts it, 'eternal presences or an epic tradition embodying logical connections, accounts which respectively have too Platonic and too Hegelian an aura' (1999: 315). Historians who approach past political thought with the belief in the existence of such universal or transcendental issues are not only reliant on metaphysical commitments that are too controversial to be sustainable; they are also likely to fall prey to the various interpretive mythologies Skinner unearths. So, for example, if an historian believes that there is a universal or transcendental concept of 'the separation of executive from legislative power' that simply 'exists' eternally, then that scholar might claim to discover it in the writings of Marsilius of Padua, despite the fact that its historical emergence can be dated two centuries after that author's death (Skinner, 2002: 60).

The claim that there are no perennial problems in philosophy is a completely different sort of argument from the first claim about eternal problems. Whether or not philosophical problems 'last a very long time' is something that cannot simply be asserted in the same manner; that is to say, it surely makes little sense as an ontological claim. At least, if it were meant to be an argument advanced at the 
ontological level, then it would be far more controversial than the claim about the non-existence of eternal problems. Scepticism about philosophical problems that simply exist eternally or infinitely seems well founded if only by default; to suggest that some issues are timeless begs a number of tricky metaphysical questions that perhaps cannot be answered. By contrast, scepticism about perennial issues is scepticism about the longevity of the existence of philosophical problems or questions and the notion that for some reason problems or questions simply cannot last a long time seems not only not self-evident or uncontroversial, but also severely counterintuitive and in need of some substantial evidence or argument in support of it. But what possible ontological evidence (or argument) could there be presented to suggest that ideas cannot last a long time? The claim made by Skinner (and not Collingwood) that there are 'no perennial questions in philosophy' would, then, seem capable only of construal as an empirical rather than ontological claim. Whilst there does not seem to be any possible philosophical argument available in defence of Skinner's denial of the perennial, his denial could make sense as a historical claim.

But if it is an empirical argument, it must then be subject to verification and it would therefore be necessary to establish through historical evidence whether or not a particular philosophical problem has a perennial existence or not. If it is an empirical argument, it cannot then simply be taken as a given truth, one that defies the possibility of its being disproved. But if this is the case, then the original thrust of Skinner's claim (and the methodological conclusion that follows from it) is undermined. This is because as soon as the question of perennial problems becomes an empirical one, the contextualist approach to the historical text relinquishes the exclusive privilege that Skinner attempts to accord it. Thus, once it can be established that the notion of a 'separation of legislative from executive power' was 
conceptualised at a given point in the past, historical research can presumably then reveal which subsequent thinkers then went on to invoke, deploy and contest it.

Intriguingly, following his assertion that 'perennial' questions or problems cannot exist in philosophy, Skinner appears to contradict it, apparently acknowledging the longevity of political ideas:

To say this is not to deny that there have been long continuities in Western moral, social and political philosophy, and that these have been reflected in the stable employment of a number of key concepts and modes of argument. It is only to say that there are good reasons for not continuing to organise our histories around the study of such continuities, so that we end up with yet more studies of the kind in which, say, the views of Plato, Augustine, Hobbes and Marx on 'the nature of the just state' are laid out and compared (2002: 86).

This statement clearly does not cohere with the rejection of the existence of perennial problems and his expressed view that the abstract use of the ideas expressed in a text is 'inherently misguided' and 'cannot in principle' succeed. One possible explanation for this contradiction could be that the denunciation of perennial problems relied on the aforementioned colloquial conflation with eternal problems. Perhaps Skinner merely intended to invoke the ontological claim made by Collingwood. Such a reading of his project looks more credible when his recent work as an historian is taken into account. His historical writing has been increasingly devoted to 'excavating' a neo-roman conceptualisation of individual liberty from the writing of Machiavelli and others (e.g. Skinner 1983; 1984; 1998). It clearly presupposes the possibility of perennial problems - the problem of how best to understand individual freedom - even if the initial objective of his methodological writings were intended to dissuade historians from assuming their existence. Nevertheless, there is something quite odd about making claims about Skinner's methodological principles based on analysis of his historical practice, because there is no logical connection between the two. The question of whether he consistently practices as an historian what he 
preaches as a methodologist might be of interest to some, but the answer has no necessary bearing on questions about the intrinsic worth of either the practice or the preaching. The fact that Skinner's historical work apparently recognises the existence of perennial problems does not mean that the methodology he defends allows him to.

But the important point is that if Skinner is read along these lines and he intends only to deny the existence of perennial problems understood in the strong, eternal sense, nothing methodologically prescriptive follows from this. As already suggested, the non-existence of eternal philosophical problems has no necessary methodological implications. We can see this by drawing a distinction between eternal problems, the existence of which requires a commitment to controversial metaphysical presumptions and perennial problems, the existence of which is a contingent social fact. So, to borrow John Searle's (1995) parlance, the non-existence of eternal problems is a 'brute fact', a natural fact about the world. But the non-existence of a brute fact has no bearing on the existence of an 'institutional fact', which is reliant only on human collective intentionality in order for it to exist. Thus, for Searle, although property, marriage or football teams do not exist as 'brute facts' (in the way that, say, molecules do), they do exist as institutional facts. In a parallel sense, because we cannot move from the denial of a brute fact to the denial of an institutional fact, property, marriage and football teams might not exist as eternal concepts or entities, but this does not mean that they cannot exist as perennial ones.

The crucial point, then, is that the move seemingly made by Skinner from the premise that there are no 'eternal' problems (Collingwood's claim) to the conclusion that there can be no 'perennial' problems is an illegitimate one. Historical analysis might demonstrate that thinkers in different times and places were talking about things that are radically incommensurable. Or it might not. But the question of 
whether or not they were talking about different things must be something assessable historically without any undefended assumptions one-way or the other. Moreover, since it would seem to be a key feature of individual speech that it can (knowingly or not) repeat the speech of others, a plausible presumption is that thinkers in different times and places can discuss the same philosophical questions: there surely can be perennial questions in philosophy even if there need not be. ${ }^{10}$ So, ultimately, whether or not the political arguments of past political thinkers address perennial questions would seem to be a matter to be settled empirically and it is possible to believe that they do address perennial questions without entertaining a corresponding belief in pre-existing eternal political questions that all thinkers must address. Bevir thus seems right to suggest that 'the burden of proof surely rests with the opponents of perennial problems who must show us that all problems discussed in classic works are illusory' (1994: 667). The assumption that there cannot be perennial problems or questions that characterise political theory is ultimately as mistaken as the assumption that there must be, so although Skinner departs from the concerns of the 'great texts' tradition and Lovejoy's notion of trans-historical 'unit-ideas', his philosophy of history actually seems flawed for very similar reasons.

\section{Ideology and Normative Argument: The Purpose of Political Speech-Acts}

If Skinner's methodology can accept the existence of perennial problems, then the original force of his arguments seems to have been surrendered insofar as other interpretive approaches retain their legitimacy and if it cannot, then it must be rejected because whether or not there are perennial issues is a question that must remain open to historical verification or refutation through evidence and argument. But Skinner's attack on the use of historical texts as abstract works of philosophy that discuss 
perennial problems is given an additional justification in Visions of Politics, one absent from his previous methodological writings and which is built on a characterisation of the authorial intentions that lie behind the composition of political texts. As noted, one of the main problems that Skinner identified in both 'great text' and epiphenomenal traditions was the lack of proper attention given to authorial intentions. In simple terms, the claim is that in order to understand the meaning of Locke's Second Treatise, the historian must determine what Locke's intention was in writing it and that the most effective way of doing this is to approach each political text as a performative speech-act and determine the 'illocutionary force' of that speech-act — a task that can only be accomplished contextually through an analysis of existing linguistic conventions. Thus, the way that one can refute Macpherson's claim that Locke was an apologist for capitalism would be to show that this particular intention was not available to him at the time of writing. The task would subsequently be to focus on those intentions that were available to Locke and determine the meaning of the speech-act accordingly.

But what if it can be established evidentially that the authorial intention itself was actually to make an abstract philosophical statement that was not particularistic, one that was actually accessible beyond the context within which it was conceived and that a philosopher wishes to use this statement in contemporary discussions of an issue or problem? In Visions of Politics Skinner's concern seems to be to demonstrate its illegitimacy by arguing not merely that authors are unable to advance abstract arguments, but rather that they are actually unable to intend to advance an abstract argument and that authorial intentions themselves are necessarily local and particularistic. The claim he puts forward then is not just that political texts must be understood as forms of political action, but also that each political action must be 
understood in particularistic terms. Interestingly, when it comes to offering a justification for this contention, Skinner appears to offer a narrow account of authorial intention, one that is actually fixed in the sense that it relies on certain ahistorical assumptions about the motivation for political action. Analysis of this account suggests an eliding of the distinction between intentions and motives and a denial of the location of meaning in the mental activity of individuals, which seems to render his revised contextualism a species of the very kind of epiphenomenalism that was a target of his earlier methodological interventions.

In mainly the last three chapters of Visions of Politics, Skinner offers an account of what he regards to be the necessarily 'ideological' underpinnings of moral and political theorizing, which he then uses to criticise what he views as the ahistorical, universalistic pretensions of normative political theory and defend his own particularistic understanding of speech-acts. He claims that past political texts should be regarded as having been composed by 'innovating ideologists' (2002: 148). These 'innovating ideologists' are individuals who attempt to rhetorically manipulate key terms through 'sleights of hand' in order to serve specific political ends, because they are aware that 'it is in large part by the rhetorical manipulation of these terms that any society succeeds in establishing, upholding, questioning or altering its moral identity' (2002: 182, 149). 'The defining task' of such ideologists is 'legitimising some form of social behaviour generally agreed to be questionable' for their own personal gain (2002: 148). According to Skinner, the paradigmatic example of such innovating ideologists can be found in Weber's The Protestant Ethic and the Spirit of Capitalism, which shows how a group of individuals, in this case mercantilists in modern Europe, were able to legitimise or justify their behaviour through recourse to an ideological discourse, which attempted to alter the meaning of key moral terms. Skinner 
generalises from this example to refute the Namierite tendency to divorce an individual's professed principles from causal accounts of that individual's actions.

In invoking this account of the 'innovating ideologist' who seeks to rhetorically manipulate key moral terms for political ends, Skinner declares his 'allegiance to one particular tradition of twentieth-century social thought', a tradition that he claims 'may perhaps be said to stem from Nietzsche' and the 'social philosophy of Max Weber' (2002: 176). Skinner further uses allegiance to this tradition to attempt a critique of normative political theory. He claims that if we accept the existence of 'innovating ideologists' and accept their role in the 'shifting conceptualisations' of key moral and political terms like justice, power or equality, then we must 'place a question-mark against' any theoretical approaches that attempt 'definitively to fix the analysis' of those terms (2002: 176-77). ${ }^{11}$ 'Normative concepts' should, he asserts, be regarded 'as tools and weapons of ideological debate', an insight he relates to 'Foucault's Nietzschean contention that "the history which bears and determines us has the form of a war"” (2002: 177).

It is important, at this stage, to try and get to grips with exactly what Skinner means by the term 'ideological', which is notoriously slippery and has a number of different significations. In its loosest, most benign form, ideology can simply refer to a body of thought and on this understanding an 'innovating ideologist' could just be the defender of an innovative body of thought. But this does not seem to be what Skinner has in mind. On the one occasion where he defines an ideological argument, it is described vaguely as one that is 'intertwined with claims to social power' (2002: 6-7). This seems to suggest he is using the term not in the benign sense of simply meaning a body of thought but rather in a more critical sense, one that involves a rhetorical strategy aimed at achieving some sort of distortion. Such critical accounts 
are staples of traditional Marxist and feminist accounts of political life and in these accounts an 'ideologist' would be an individual acting to legitimate a certain distorted way of thinking or behaving. What distinguishes Skinner's account of ideology from other critical accounts of ideology is that unlike traditional Marxist or feminist accounts that tend to locate ideology in a source (like capitalism or patriarchy), his is apparently dislocated: it does not emanate from one totality. Given his vision of speech-acts as particular rhetorical moves designed to bring about a state of affairs desired by the author through distortion and the dislocation of these claims to social power from traditional sources, Skinner's conception of ideology could perhaps also be read as some sort of Foucauldian account. But unlike Skinner, Foucault's writing - in common with that of most philosophers identified as post-Marxist and post-structuralist - displays a marked suspicion of the entire concept of 'ideology', as it implies a binary opposite notion of 'truth' (Foucault, 2001). ${ }^{12}$

Skinner's focus on utterances as ideologically manipulative statements that are designed to bring about a certain state of affairs has been praised by scholars like Palonen (1997; 2003), who describes it as enabling a 'rhetorical perspective' on the history of political thought and political theorizing in general. ${ }^{13}$ But, again, as with the perennial/eternal distinction drawn earlier, Skinner's account of ideological actionand the rhetorical perspective it facilitates — rests either on a claim that provides justification for his contextualism but is false or on one that is true but provides no such justification. Skinner's argument might rest on (1) the weaker claim that all political utterances involve claims to social power and are therefore ideological in some respect or (2) on the more extreme claim that all political utterances are purely ideological and therefore only comprehensible in ideological terms. Which of these two claims is being pushed matters because they lend different sorts of support for his 
methodological arguments. If the former, weaker claim is accepted, then we can allow that while all utterances have an ideological element—in the sense that they represent claims to social power- they are not reducible to this ideological element. This is because even if it is granted that individual utterances always reflect a wish to impose a particular moral vision on the world, they will also necessarily refer to that vision in the sense that they express their viewpoints and beliefs. But as soon as this is admitted, the object of study can shift legitimately to the viewpoints and beliefs expressed by an individual at a specified level of abstraction rather than any concern with illocutionary force. Thus, on the acceptable, weaker version of Skinner's account of ideology, his methodology relinquishes the exclusive status he seems to want for it. There is no need to consider utterances as ideologically motivated and particularistic speech-acts and no need to adopt linguistic contextualism.

But Skinner does, at times, appear to endorse the more extreme account that would lend exclusive support to his particularistic linguistic contextualism and sees utterances as comprehensible in only ideological terms. This endorsement appears in his critique of normative political theory. For Skinner,

... all attempts to legislate about the 'correct' use of normative terms must be regarded as equally ideological in character. Whenever such terms are employed, their application will always reflect a wish to impose a particular moral vision on the workings of the social world (2002: 182).

There are, he further suggests, 'ideological motivations underlying even the most abstract systems of thought' and because of this 'no one is above the battle, because the battle is all there is' (2002: 6-7, emphasis added). So, because all political speech acts are ideological (insofar as they are seeking to justify a particular claim to social power through 'sleight of hand'), they cannot be abstract philosophical statements in the way that is often supposed. It is not just because all political speech represents actions but also because all actions are ideological that individual thinkers cannot 
advance arguments that are abstractly philosophical. Thus, when Skinner asserts that 'the only histories of ideas to be written are histories of their uses in argument' (2002: 86), he assumes that moral ideas are invariably used in a purely rhetorical and strategic manner and therefore it is particularistic, ideological argument that is to be the object of study for the historian of ideas. There can therefore be no perennial problems 'beneath the surface of ideological debate' because of the 'radical contingency in the history of thought' (2002: 176).

But the problem with this suggestion is that the claim that all normative utterances are purely ideological presents an unjustifiably narrow and essentialist view of authorial intentions that is as controversial as that of the epiphenomenalism that Skinner is so keen to reject. As with the question of the existence of perennial problems, whether an utterance should be appreciated primarily at the level of ideology would seem to be something that has to be settled through evidence and argument rather than be presumed at the outset of analysis. What is often regarded as the key strength of Skinner's approach is that it represents a properly contextualist, almost anthropological, hermeneutic, one committed to 'seeing things their way' (Skinner, 2002: 1-7, emphasis added) and thus privileges thick cultural context over ahistorical universalisms. But, if he holds onto such a fixed, essentialist view of the intentions that lie behind political speech (that political speech is always geared towards a particular end and that this end is 'social power'), his approach fails to live up to its promise, insofar as it assumes a stable (ideological) human motivation for (speech-) action, one that spans across contexts, cultures and time. Such an assumption would surely beg as tricky metaphysical questions as any professed belief in eternal philosophical problems. In making it, he effectively elides the same distinction as the epiphenomenal approach between intentions and motives, because 
the former have no existence independent of the latter. The only way to uncover the meaning of a political speech-act is to look for the ideology the writer attempts to justify, the outcome she was attempting to generate, rather than intentionality in the broader sense of the possible beliefs held by an individual and which ones that individual tried to express in a particular text.

It would seem perfectly plausible that a statement made for some ideological purpose could also be considered an abstract philosophical statement. There does not seem any compelling reason to think that one category must exclude the other. Furthermore, the abstract philosophical statement in question could be a normative one. Consider, for example, a detailed argument in defence of the ethical practice of eating non-human animals. Such an argument could surely operate (and therefore be open to inspection and evaluation) at (at least) two different levels. On the one hand, it could be a clearly ideological statement, in that it seeks to alter the social world to serve some disguised end (suppose that the author of the argument happened to be a butcher with a vested financial or cultural interest in the continuation of this particular ethical practice). But, surely, on the other, it also can belong to the genre of philosophical moral argument provided it meets certain (quite loose) criteria? On what grounds can it be excluded from consideration as an abstract statement? We might want to treat the argument with suspicion given its origins, but this suspicion would not necessarily undermine its efficacy as a philosophical argument. The key point is that even if it were admitted that 'no one is above the battle' it does not follow from this that 'the battle is all there is' if the 'battle' in question is considered fought solely at the level of ideology. There are no compelling grounds to reduce the meaning of an utterance to its performative function. But even if there were such 
grounds, it seems quite wrong to conceive such performances in such narrowly ideological terms.

\section{Conclusion}

I have argued that Quentin Skinner's revised historical contextualism attempts to impugn the legitimacy of certain other approaches to interpretation and understanding, most notably the study of past texts as works of abstract political philosophy. My claim is that the justifications that Skinner provides for the deployment of his own contextualist understanding of political texts are indefensible in part because his method presupposes things that a historian should never presuppose. The first is that philosophical problems or questions cannot be perennial (exist over a long period of time), a claim that has to be borne out evidentially and should not be assumed — not least because it seems so obvious that many such problems or questions do occupy philosophical attention for a long time. The second is that political speech acts are inevitably ideological, in the sense that they are intended to justify power claims. This is something that also should not be assumed from the outset of analysis and seems additionally dubious given the lack of any compelling reason to ever appreciate an argument as purely ideological. Ultimately, these justifications risk rendering Skinner's contextualism a form of epiphenomenalism, though of a seemingly Nietzschean rather than Marxist or Namierite bent because of the reduction of individual intentionality to ideological motivation, a reduction that locates the meaning of an utterance to a pre-defined will to achieve social power rather than to any meaningful mental activity of the individual in question. 
It should be again noted that the aim of this article has not been to undermine the entire thrust of Skinner's writing on historical interpretation. It has rather been to undermine its apparent claim to exclusivity and corresponding critique of the study of past thought as anything other than particularistic rhetoric. Were this claim to exclusivity relinquished Skinner's arguments would then likewise relinquish their status as methodological claims and instead become matters of mere heuristic techniques. The contention that 'there can be no perennial problems' could thus be rephrased, changed to the contention that 'it is usually unwise to approach a text with the assumption that it was written to address perennial problems'. But, as intimated earlier, any such relinquishment would seem contrary to the spirit of Skinner's writings, both against the use of 'great texts' to inform contemporary discussions and against the universalism of normative political theory, the dismissal of which require more than merely arguments about heuristics. But when presented in terms stronger than this, Skinner's contextualism is unsustainable and there is no reason why historical works of political thought cannot be studied as abstract, philosophical speech-acts that are potentially capable of trans-historical comprehensibility.

Any defence of the legitimacy of studying perennial problems in political philosophy raises further questions. One such question would likely concern the danger of endorsing some sort of naïve methodological pluralism where we can use past texts however we please, without due sensitivity to various aspects of historical context. To this the obvious response is that no such pluralism need follow from an admission of the possibility of perennial problems. Indeed, placing due emphasis on the importance of determining levels of abstraction should reveal the vacuity of any strong juxtaposition of historical and philosophical understanding. Any claim that a particular problem is perennial or that a particular argument is intended for 
comprehension beyond its immediate temporal horizons requires substantiation with relevant evidence and argument. Political theorists cannot claim that past works mean anything they like whilst claiming to be engaged in historical interpretation. But they can treat past works as relevant to contemporary philosophical concerns without an obsessive concern with anachronism.

Another pertinent question might concern the value of looking for historical answers to perennial problems in the first place. Would political theorists not be better off, as Skinner himself has suggested, to 'learn to do our thinking for ourselves' (2002: 88) rather than recycle ideas from the past? There does not seem to me to be any certain answer to this question. Whether or not past political thinkers are thought to have something to say will always be a matter of some contingency. Nevertheless, it seems inevitable that encounters and critical engagements with the concepts and intellectual traditions that have been bequeathed to us, as well as those alien to us both temporally and culturally, have an obvious utility. Indeed, the post-metaphysical turn taken by both normative and critical political theory in the late twentieth-century seems to suggest every reason to explore the ideas of the past, as they chime with, challenge or provoke our intuitions about what Janet Coleman has described - with characteristic perspicuity — as 'the kinds of questions one asks oneself at four in the morning: what are we here for and what kind of person do I wish to be and in what kind of society?' (2002: 152). 


\section{References}

Ball, T. (2007) 'Professor Skinner's Visions', Political Studies Review 5: 351-364.

Bevir, M. (1992) 'The Errors of Linguistic Contextualism', History and Theory 31: 276-98.

Bevir (1994) 'Are There Perennial Problems in Political Theory?', Political Studies 42: 662-75.

Bevir (1999) The Logic of the History of Ideas, Cambridge.

Bevir (forthcoming) 'The Contextual Approach' in G. Klosko (ed.) The Oxford Handbook for the History of Political Thought, Oxford.

Castiglione, D. (1993) 'Historical Arguments in Political Theory', Political Theory Newsletter 5: 89-109.

Cohen, G.A. (1978) Karl Marx's Theory of History: A Defence, Oxford.

Coleman, J. (2000) 'The History of Political Thought in a Modern University', History of Political Thought 21: 152-171

Collingwood, R.G. (1970) An Autobiography, Oxford.

Dunn, J. (1968) 'The Identity of the History of Ideas', Philosophy 43: 85-116

Dunn, J. (1996) 'The History of Political Theory' in Dunn The History of Political Theory and Other Essays, Cambridge.

Foucault, M. (2001) 'Truth and Power' in James D. Faubion (ed.) Power: Essential Works of Foucault 1954-1984, Volume 3, London, pp. 111-133.

Hampsher-Monk, I. (1998) 'Speech Acts, Languages or Conceptual History?' in Hampsher-Monk, K. Tilmans and F. Van Vree (eds.) History of Concepts: Comparative Perspectives, Amsterdam.

Hampsher-Monk, I. (2001) 'The History of Political Thought and the Political History of Thought' in D. Castiglione and I. Hampsher-Monk (eds.) The History of Political Thought in National Context, Cambridge.

Kavka, G.S. (1986) Hobbesian Moral and Political Theory, Princeton.

Lamb, R. (2009) 'Recent Developments in the thought of Quentin Skinner and the Ambitions of Contextualism', Journal of the Philosophy of History 3:

Lovejoy, The Great Chain of Being: A Study of the History of an Idea (Cambridge MA, 1936).

Macpherson, C.B. (1962) The Political Theory of Possessive Individualism: Hobbes to Locke, Oxford.

Otsuka, M. (2003) Libertarianism without Inequality, Oxford.

Palonen, K. (1997) 'Quentin Skinner's Rhetoric of Conceptual Change', History of the Human Sciences 10: 61-80.

Palonen, (2000) 'Logic or Rhetoric in the History of Political Thought? Comments on Mark Bevir', Rethinking History 4: 301-10.

Palonen, (2002) 'The History of Concepts as a Style of Political Theorizing: Quentin Skinner's and Reinhart Koselleck's Subversion of Normative Political Theory', European Journal of Political Theory 1: 91-106

Palonen, K. (2003) Quentin Skinner: History, Politics, Rhetoric, Cambridge.

Pallares-Burke, M-L. (2002) 'Interview with Quentin Skinner' in Pallares-Burke (ed.) The New History: Confessions and Conversations, Cambridge.

Pocock, J.G.A. (1985) 'Introduction: the state of the art' in Pocock, Virtue, Commerce, and History: Essays on Political Thought and History, Chiefly in the Eighteenth Century, Cambridge.

Pocock, J.G.A. (2004) 'Quentin Skinner: The History of Politics and the Politics of History', Common Knowledge 10: 532-550 
Searle, J. (1995) The Construction of Social Reality, Oxford.

Sebastián, J. F. (2007) 'Intellectual History, Liberty and Republicanism: An Interview with Quentin Skinner', Contributions to the History of Concepts 3: 103-23.

Skinner, Q. (1983) 'Machiavelli on the Maintenance of Liberty', Politics 18: 3-15.

Skinner, Q. (1984) 'The Idea of Negative Liberty: Philosophical and Historical Perspectives' in Richard Rorty, J.B. Schneewind and Quentin Skinner (eds.), Philosophy in History, Cambridge.

Skinner, Q. (1998) Liberty before Liberalism, Cambridge.

Skinner, Q. (2002) Visions of Politics: Volume 1: Regarding Method, Cambridge.

Tuck, R. (1993) 'The Contribution of History' in Robert E. Goodin and Philip Pettit (eds.) A Companion to Contemporary Political Philosophy, Oxford.

Tully, J. (1988) 'The pen is a mighty sword: Quentin Skinner's analysis of politics' in Tully (ed.) Meaning and Context: Quentin Skinner and his critics, Cambridge.

Waldron, J. (2002) God, Locke, and Equality: Christian Foundations in Locke's Political Thought, Cambridge.

\section{Notes}

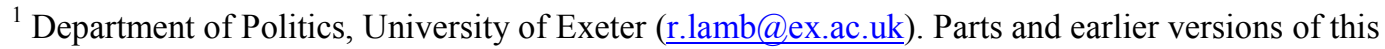
paper have been presented at various seminars at Exeter over the last couple of years. I am grateful to the audiences there (especially the Political Theory group for their patience as I gradually worked out what it was I didn't like about Cambridge School linguistic contextualism), to the HHS referees and to James Penner, Mark Philp, Nikola Regent and Ben Thompson for comments and criticism. I owe particularly huge thanks to Mark Bevir, Dario Castiglione and Iain Hampsher-Monk for numerous debates and discussions of Skinner's work and related issues.

${ }^{2}$ The rather misleading nature of the popular label 'Cambridge School' should be noted and the absence of any single contextualist method emphasised. Indeed, the two best-known defenders of historical contextualism, Quentin Skinner and J.G.A. Pocock defend quite distinct (and not necessarily logically compatible) methodological approaches, with the former focusing on synchronic 'speechacts' and the latter on diachronic 'languages'. See Pocock (1985) for his account of the difference. For further discussion of the similarities and differences between their two approaches, see Bevir (1992) where the difference is expressed as one of 'soft' (Skinner) and 'hard' (Pocock) linguistic contextualism; and also Hampsher-Monk (1998).

${ }^{3}$ For my attempt at this, see Lamb (2009)

${ }^{4}$ This is not to say that these were the only traditions that Skinner's methodological writings were aimed against. Another anti-historical and still influential tradition that he is hostile towards is that associated with Leo Strauss.

${ }^{5}$ In interviews, Skinner has specifically cited these 'two prevailing approaches to intellectual history' as the 'targets' of his 'manifesto' (Pallares-Burke, 2002: 218-19; Sebastián, 2007).

${ }^{6}$ One of the $H H S$ reviewers objected strongly to my use of Bevir's method/heuristic distinction on the grounds that no such distinction is acknowledged by Skinner or is identifiable in his work. This complaint strikes me as very odd. Surely it is legitimate to present and assess a theory through concepts unfamiliar to its author, provided that those concepts are themselves sound and, in this case, that the distinction is illuminating.

${ }^{7}$ John Dunn $(1968 ; 1996)$ has certainly made a number of important contributions to discussions of this topic but they have been more critical than constructive and he has never attempted to lay down any discernible set of interpretive rules. Tully (1988) has also made scattered methodological statements but he presents his approach as fundamentally indebted to that of Skinner — or at least, a Foucauldian reading of Skinner.

${ }^{8}$ For discussion of this dual role of language, see Pocock (1985) and Hampsher-Monk (2001). The issue of agency is a very tricky one for interpreters of Skinner, since his writings on method (especially his early work) can be plausibly read as committed to a strictly conventionalist theory of meaning (see, 
for example, Bevir, 1999: 40-52), which would seem unable to explain the dynamics of conceptual change.

${ }^{9}$ As Dunn suggested, the problem with the Marxist approach is that it paid 'only the most perfunctory (or insincere) attention to the concerns of the author, and stresses instead the aspects of the historical society in which the text was composed, of which its author might well have been imperfectly aware but which, nevertheless, prompted him or her to think and express themselves as they did' (1996: 19).

${ }^{10}$ Bevir (1994) has gone further and made the case for a principle of translatability for webs of beliefs that compels us to accept the existence of perennial problems: 'We must share some beliefs with the authors of classic works of political theory otherwise we could not translate these works into our vocabulary. In general, if we could not translate a work as an expression of a web of beliefs many of which we considered to be true and rational, we could not conceive of the work as expressive of intelligible beliefs, so we could not translate the work at all....In short, because we must accept that we can translate past works into our vocabulary, we also must accept that we share some beliefs with the authors of past works' (666-67).

${ }^{11}$ Skinner singles out 'Neo-Kantian' approaches, which clearly suggests it is John Rawls and his followers whom he has in mind, but his critique would seem to take in all contemporary normative political theory.

${ }^{12}$ Foucault lists three reasons why 'the notion of ideology appears to me to be difficult to make use of', the first of which is that 'it always stands in virtual opposition to something else that is supposed to count as truth' (2001: 119).

${ }^{13}$ This description is endorsed by Skinner (2002: 179). 